\title{
Effect of Low Environmental Temperature on Performance and Blood System in Broiler Chickens (Gallus domesticus)
}

\author{
J. BLAHOVÁ ${ }^{1}$, R. DOBŠÍKOVÁ ${ }^{1}$, E. STRAKOVÁ², P. SUCHÝ² \\ ${ }^{1}$ Department of Veterinary Public Health and Toxicology \\ ${ }^{2}$ Department of Nutrition, Animal Husbandry and Animal Hygiene, Faculty of Veterinary Hygiene \\ and Technology, University of Veterinary and Pharmaceutical Sciences Brno, Czech Republic \\ Received October 2, 2006 \\ Accepted February 20, 2007
}

\begin{abstract}
Blahová J., R. Dobšíková, E. Straková, P. Suchý: Effect of Low Environmental Temperature on Performance and Blood System in Broiler Chickens (Gallus domesticus). Acta Vet. Brno 2007, 76: S17-S23.

The aim of this study was to assess the effect of low environmental temperature on growth, feed conversion, performance and selected biochemical and haematological indicators in broiler chickens. The decrease in air temperature since the $22^{\text {nd }}$ day of growth influenced significantly $(p<0.05)$ the level of total proteins, uric acid, phosphorus (in female broiler chickens), glucose (in male broiler chickens), haemoglobin (in female broiler chickens) and liver weight (in male broiler chickens). The temperature influenced significantly $(p<0.01)$ the level of triiodothyronine, haemoglobin (in male broiler chickens), haematocrit, abdominal fat content (in male broiler chickens), and heart weight too. The results have clearly confirmed that during growth, the decrease in environmental temperature (cold stress) negatively influenced some indices of performance and blood system in broiler chickens.
\end{abstract}

Poultry, ambient temperature, stress, biochemical and haematological indicators, carcass efficiency

The changes in environmental temperature below and above the thermal comfort zone have a negative effect on bird performance. Broiler chicken is a homeotherm that can live comfortably only in a relatively narrow zone of thermoneutrality. Both low and high temperatures act in a negative way. Low environmental temperature increases feed intake and decreases body weight gain and feed efficiency, thus negatively influencing the performance of broiler chickens. As Manning and Wyatt (1990) proved, broiler chickens adapted more easily to lower than to higher temperature. The optimal temperature range for efficient production for broiler chickens over 4 weeks of age is $18-21^{\circ} \mathrm{C}$ (Aengwanich and Simaraks 2004).

Shinder et al. (2002) reported that short-term cold conditioning of chickens at an early age could induce an improvement either in thermotolerance during cold challenge or in performance of chickens exposed to an optimal environmental temperature.

The increase in energy requirement as a result of exposure to low environmental temperature implies neccessary changes in the cardiovascular system to accommodate the energy needs. Thus, increases in haematocrit, haemoglobin concentration, blood volume, liver and heart muscle weight have been observed in broiler chickens and turkeys exposed to low environmental temperature (Yahav et al. 1996; Yahav 2002). Yahav et al. (1997) reported linear relationship between haematocrit and heart weight under constant temperature. The observed relationship indicates an adaptation of heart mass to the changes in work load associated with the changes in blood flow resistance. Cahaner and Leenstra (1992) documented that abdominal fat content was affected by environmental temperature. In cooler environment, more energy was dissipated as heat and thus fat accumulation was decreased.

Plasma triiodothyronine $\left(\mathrm{T}_{3}\right)$ is associated with a temperature regulation and is an important

Address for correspondence:

Ing. Jana Blahová

University of Veterinary and Pharmaceutical Sciences

Palackého 1-3, 61242 Brno

Czech Republic

Phone: +420 541562785

Fax: +420 541562790

E-mail: blahovaj@vfu.cz

http://www.vfu.cz/acta-vet/actavet.htm 
growth promoter in broiler chickens. $\mathrm{T}_{3}$ may be involved in the modification of growth rate by ambient temperature (Darras et al. 2000; Stojević et al. 2000). The circulating $\mathrm{T}_{3}$ concentration appears to be linearly correlated negatively and positively with temperature and feed intake, respectively (Klandorf and Harvey 1985; Yahav et al. 1995; Yahav 2000).

In the present study the effect of low environmental temperature on broiler chickens performance and selected indices of blood system was studied.

\section{Materials and Methods}

Experimental procedure

In this study, 120 1-day-old female and male broiler chickens (ROSS 308) obtained from a commercial hatchery were used. The animals were divided into two groups - female and male, including 60 chickens in each. Chickens were kept on a deep bedding in an accredited experimental facility of the Department of Nutrition, Animal Husbandry and Animal Hygiene (Faculty of Veterinary Hygiene and Ecology, University of Veterinary and Pharmaceutical Sciences Brno, Czech Republic). The experimental facility was equipped with airconditioning, automated feeding and watering of chickens, which enabled to monitor continually the consumption of feed and water and to record temperature and relative air humidity. Chickens were fed ad libitum with feeding mixtures complying with all nutritional and caloric requirements (BR 1 - from $1^{\text {st }}$ to $21^{\text {st }}$ day, BR 2 - from $22^{\text {nd }}$ to $36^{\text {th }}$ day and BR $3-$ from $37^{\text {th }}$ to $42^{\text {nd }}$ day). Both groups were subjected to the same temperature regimen till $21^{\text {st }}$ day of age. Subsequently the ambient temperature was decreased as follows: $31^{\circ} \mathrm{C}$ during the first two days and $30^{\circ} \mathrm{C}, 28^{\circ} \mathrm{C}, 26^{\circ} \mathrm{C}$, and $24^{\circ} \mathrm{C}$ up to the end of $4^{\text {th }}, 8^{\text {th }}, 15^{\text {th }}$, and $21^{\text {st }}$ day, respectively. At the age of 22 days, the groups of female and male broiler chickens were divided into control (30 female and 30 male specimens) and experimental (30 female and 30 male specimens) groups. The experimental groups of males and females were transferred into the animal house, in which the temperature was not adjusted and depended on outdoor climatic conditions. The ambient temperature in the control groups decreased from 24 to $21^{\circ} \mathrm{C}$ since $22^{\text {nd }}$ day to $42^{\text {nd }}$ day of age. The temperature in the experimental groups was continually monitored and ranged between 4 and $13^{\circ} \mathrm{C}$ (Fig. 1). To provide them cold stress conditions, the broilers were reared during cold months (January 31 - March $13,2006)$. In the course of growth, feed consumption, mortality and health conditions of chickens were observed continuously.

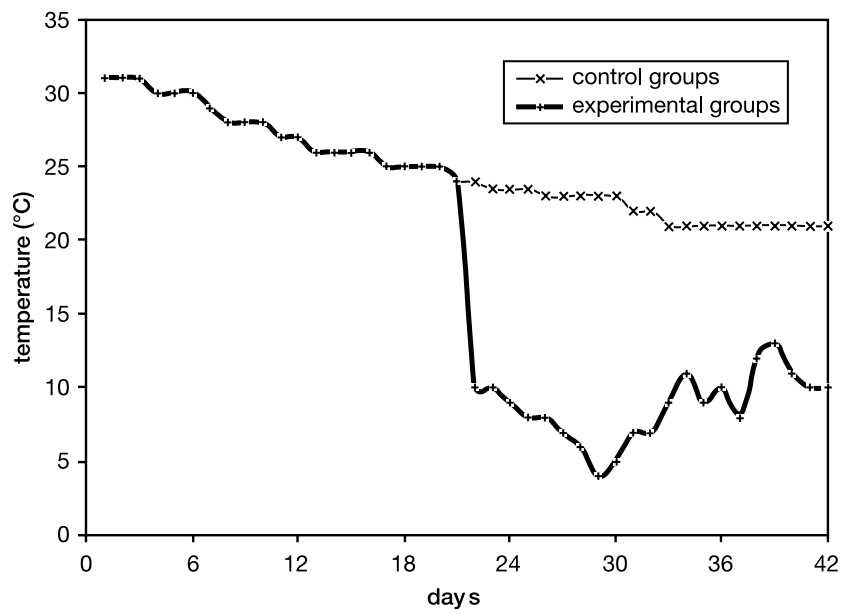

Fig. 1. Monitored environmental temperature in control and experimental groups (female and male) during fattening

At $1^{\text {st }}, 10^{\text {th }}, 22^{\text {nd }}, 30^{\text {th }}$, and $42^{\text {nd }}$ day of growth, body weights were measured in each group. At $22^{\text {nd }}$ and $42^{\text {nd }}$ day of growth, blood of randomly selected twenty chickens in each group was obtained. Venous blood samples were collected by puncture of a wing vein (vena basilica) into heparinised tubes.

Biochemical analysis

Blood samples were centrifuged at $800 \mathrm{~g}$ for $10 \mathrm{~min}$ and plasma was collected and stored deep frozen $\left(-80^{\circ} \mathrm{C}\right.$ ) for later analysis (up to one month). Plasma biochemical indices (glucose, total proteins, uric acid, 
triglycerides, cholesterol, calcium, phosphorus, and magnesium) were measured by a biochemical analyzer Cobas EMira using commercial test kits (BioVendor). Plasma level of total $\mathrm{T}_{3}$ was measured by a biochemical analyzer IMMULITE 1 (DPC).

Haematological analysis

Haematological examination (Doubek 2003) of heparinised blood consisted of the following tests: erythrocyte and leucocyte count (using flask dilution method and counting blood cells under a microscope using a Bürker chamber), haematocrit value (capillary micro-haematocrit method using Janetzki centrifuge) and haemoglobin content (photometrically at $540 \mathrm{~nm}$ ).

Performance and feed conversion of broiler chickens

At the end of growth, twenty chickens in each group were slaughtered and weighed to determine a slaughter efficiency. The birds were dissected to remove pairs of breast and femoral muscles, abdominal fat content, heart and liver and after $24 \mathrm{~h}$ (storage at $4^{\circ} \mathrm{C}$ ) individual parts of birds were weighed. The carcass efficiency was expressed as a percentage of body weight. The feed conversion was calculated by the proportion of the total feed consumed per each group since $22^{\text {nd }}$ to $42^{\text {nd }}$ day of growth and rising of weight since $22^{\text {nd }}$ to $42^{\text {nd }}$ day of growth.

\section{Statistical analysis}

The obtained data were subjected to statistical processing using the program UNISTAT 5.1. The differences between average values were compared using $t$-test at the levels of significance $p<0.01$ and $p<0.05$.

\section{Results}

The results of the experiment focused on the assessment of the effect of environmental temperature on fattened chickens proved decreased environmental temperature to be a very important factor affecting chicken's inner environment and subsequently their production, physiological response and health conditions.

The results (mean $\pm \mathrm{SD}$ ) of biochemical and haematological analysis and performance are given in Table $1-3$.

Table 1. Results of the biochemical analysis (day 42).

\begin{tabular}{|c|c|c|c|c|c|}
\hline \multirow{2}{*}{ Index } & \multirow{2}{*}{ Group } & \multicolumn{2}{|c|}{ Female } & \multicolumn{2}{|c|}{ Male } \\
\hline & & $x \pm \mathrm{SD}$ & $p$ & $x \pm \mathrm{SD}$ & $p$ \\
\hline \multirow{2}{*}{$\begin{array}{l}\text { Total proteins } \\
\left(\mathrm{g} \cdot \mathrm{l}^{-1}\right)\end{array}$} & $\mathrm{C}$ & $33.47 \pm 2.39$ & \multirow{2}{*}{$0.042 *$} & $32.17 \pm 2.33$ & \multirow{2}{*}{$0.028 *$} \\
\hline & $\mathrm{E}$ & $35.38 \pm 3.18$ & & $34.36 \pm 3.51$ & \\
\hline \multirow{2}{*}{$\begin{array}{l}\text { Glucose } \\
\left(\mathrm{mmol} \cdot \mathrm{l}^{-1}\right)\end{array}$} & $\mathrm{C}$ & $13.10 \pm 0.45$ & \multirow{2}{*}{0.795} & $13.01 \pm 0.91$ & \multirow{2}{*}{$0.017 *$} \\
\hline & $\mathrm{E}$ & $13.16 \pm 0.87$ & & $13.73 \pm 0.87$ & \\
\hline \multirow{2}{*}{$\begin{array}{l}\text { Uric acid } \\
\left(\mu \mathrm{mol} \cdot 1^{-1}\right)\end{array}$} & $\mathrm{C}$ & $279.24 \pm 67.13$ & \multirow{2}{*}{$0.015^{*}$} & $262.70 \pm 91.14$ & \multirow{2}{*}{$0.041 *$} \\
\hline & $\mathrm{E}$ & $339.56 \pm 80.05$ & & $334.44 \pm 118.78$ & \\
\hline \multirow{2}{*}{$\begin{array}{l}\text { Cholesterol } \\
\left(\mathrm{mmol} \cdot \mathrm{l}^{-1}\right)\end{array}$} & $\mathrm{C}$ & $3.12 \pm 0.25$ & \multirow{2}{*}{0.176} & $3.21 \pm 0.31$ & \multirow{2}{*}{0.912} \\
\hline & $\mathrm{E}$ & $2.98 \pm 0.42$ & & $3.22 \pm 0.33$ & \\
\hline \multirow{2}{*}{$\begin{array}{l}\text { Triglycerides } \\
\left(\mathrm{mmol} \cdot \mathrm{l}^{-1}\right)\end{array}$} & $\mathrm{C}$ & $0.72 \pm 0.15$ & \multirow{2}{*}{0.350} & $0.67 \pm 0.16$ & \multirow{2}{*}{0.382} \\
\hline & $\mathrm{E}$ & $0.97 \pm 0.15$ & & $0.71 \pm 0.13$ & \\
\hline \multirow{2}{*}{$\begin{array}{l}\text { Magnesium } \\
\left(\mathrm{mmol} \cdot \mathrm{l}^{-1}\right)\end{array}$} & $\mathrm{C}$ & $1.21 \pm 0.10$ & \multirow{2}{*}{0.292} & $1.20 \pm 0.08$ & \multirow{2}{*}{0.154} \\
\hline & $\mathrm{E}$ & $1.24 \pm 0.09$ & & $1.25 \pm 0.10$ & \\
\hline \multirow{2}{*}{$\begin{array}{l}\text { Calcium } \\
\left(\mathrm{mmol} \cdot \mathrm{l}^{-1}\right)\end{array}$} & $\mathrm{C}$ & $2.29 \pm 0.50$ & \multirow{2}{*}{0.148} & $2.39 \pm 0.55$ & \multirow{2}{*}{0.306} \\
\hline & $\mathrm{E}$ & $2.52 \pm 0.50$ & & $2.56 \pm 0.51$ & \\
\hline \multirow{2}{*}{$\begin{array}{l}\text { Phosphorus } \\
\left(\mathrm{mmol} \cdot \mathrm{l}^{-1}\right)\end{array}$} & $\mathrm{C}$ & $2.35 \pm 0.27$ & \multirow[b]{2}{*}{$0.013^{*}$} & $2.11 \pm 0.23$ & \multirow{2}{*}{$0.000 * *$} \\
\hline & $\mathrm{E}$ & $2.64 \pm 0.42$ & & $2.40 \pm 0.24$ & \\
\hline \multirow{2}{*}{$\begin{array}{l}\mathrm{T}_{3} \\
\left(\mathrm{ng} \cdot \mathrm{ml}^{-1}\right)\end{array}$} & $\mathrm{C}$ & $1.03 \pm 0.23$ & \multirow{2}{*}{$0.000 * *$} & $0.98 \pm 0.19$ & \multirow{2}{*}{$0.000 * *$} \\
\hline & $\mathrm{E}$ & $1.84 \pm 0.39$ & & $2.59 \pm 0.81$ & \\
\hline
\end{tabular}

$\mathrm{C}$ - control group, $\mathrm{E}$ - experimental group, $x$ = arithmetic mean, $\mathrm{T}_{3}$ - triiodothyronine

$\mathrm{SD}=$ standard deviation, $p=$ test value according to Student's $t$-test

$* p<0.05, * * p<0.01$ 
The results of plasma biochemical (Table 1) profile of experimental female and male groups exposed to low environmental temperature showed significantly increased level of total proteins $(p<0.05)$, uric acid $(p<0.05)$, phosphorus $(p<0.05$ in female and $p<0.01$ in male broiler chickens) and triiodothyronine $(p<0.01)$ in comparison with control female and male groups. In addition, in the experimental male group, low environmental temperature significantly increased the concentration of glucose $(p<0.05)$. The levels of cholesterol, triglycerides, magnesium, and calcium were comparable between the groups tested.

Table 2. Results of the haematological analysis (day 42)

\begin{tabular}{|c|c|c|c|c|c|}
\hline \multirow{2}{*}{ Index } & \multirow{2}{*}{ Group } & \multicolumn{2}{|c|}{ Female } & \multicolumn{2}{|c|}{ Male } \\
\hline & & $x \pm \mathrm{SD}$ & $p$ & $x \pm \mathrm{SD}$ & $p$ \\
\hline \multirow{2}{*}{$\begin{array}{l}\text { Erythrocytes } \\
\left(\mathrm{T} \cdot \mathrm{1}^{-1}\right)\end{array}$} & $\mathrm{C}$ & $3.05 \pm 0.26$ & \multirow{2}{*}{0.573} & $3.11 \pm 0.57$ & \multirow{2}{*}{0.209} \\
\hline & $\mathrm{E}$ & $3.00 \pm 0.34$ & & $3.32 \pm 0.46$ & \\
\hline \multirow{2}{*}{$\begin{array}{l}\text { Leukocytes } \\
\left(\mathrm{G} \cdot \mathrm{l}^{-1}\right)\end{array}$} & $\mathrm{C}$ & $27.91 \pm 7.73$ & \multirow{2}{*}{0.099} & $23.90 \pm 5.90$ & \multirow{2}{*}{0.227} \\
\hline & $E$ & $24.19 \pm 5.92$ & & $21.29 \pm 7.10$ & \\
\hline \multirow{2}{*}{$\begin{array}{l}\text { Haematocrit } \\
\left(1 \cdot 1^{-1}\right)\end{array}$} & $\mathrm{C}$ & $0.32 \pm 0.02$ & \multirow{2}{*}{$0.008 * *$} & $0.29 \pm 0.04$ & \multirow{2}{*}{$0.000 * *$} \\
\hline & $\mathrm{E}$ & $0.35 \pm 0.03$ & & $0.35 \pm 0.04$ & \\
\hline \multirow{2}{*}{$\begin{array}{l}\text { Haemoglobin } \\
\left(\mathrm{g} \cdot \mathrm{l}^{-1}\right)\end{array}$} & $\mathrm{C}$ & $92.85 \pm 6.40$ & \multirow{2}{*}{$0.024 *$} & $92.69 \pm 9.45$ & \multirow{2}{*}{$0.006 * *$} \\
\hline & $\mathrm{E}$ & $97.62 \pm 6.29$ & & $104.46 \pm 14.88$ & \\
\hline
\end{tabular}

$\mathrm{C}$ - control group, $\mathrm{E}$ - experimental group, $x=$ arithmetic mean

$\mathrm{SD}=$ standard deviation, $p=$ test value according to Student's $t$-test

$* p<0.05, * * p<0.01$

As far as the haematological indices (Table 2) are concerned, low environmental temperature caused a significant increase in haematocrit $(p<0.01)$ and haemoglobin $(p<$ 0.05 in female and $p<0.01$ in male broiler chickens). The other haematological indices tested were comparable within the groups.

The live weight of female $(2.27 \mathrm{~kg})$ and male $(2.60 \mathrm{~kg})$ broiler chickens exposed to low environmental temperature was lower than that of control groups (female - $2.33 \mathrm{~kg}$, male $2.70 \mathrm{~kg}$ ), but these values did not differ significantly. The feed conversion since $22^{\text {nd }}$ to $42^{\text {nd }}$ day of growth in experimental groups (female $-2.18 \mathrm{~kg}$, male $-2.12 \mathrm{~kg}$ ) was higher than that of control groups (female $-2.05 \mathrm{~kg}$, male $-2.03 \mathrm{~kg}$ ). As far as performance parameters (Table 3) are concerned, low environmental temperature caused an increased heart weight $(p<0.01)$ in the experimental female group and an increased heart weight $(p<0.01)$, liver weight $(p<0.05)$ and decreased abdominal fat content $(p<0.01)$ in the experimental male group. In adition, low environmental temperature significantly $(p<0.01)$ caused changes in carcass efficiency of abdominal fat (only in male broiler chickens), carcass efficiency of hearth weight and carcass efficiency of liver weight (only in male broiler chickens).

\section{Discussion}

It is well documented that growth, food intake and physiological response are changed by environmental temperature. Poultry are homeotherm animals that can live comfortably only in a relatively narrow zone of thermoneutrality. Low and high temperatures are stressful and have negative effect on economy of production and animal welfare (Yunianto et al. 1997; Aengwanich and Simaraks 2004). In our study, the effect of low environmental temperature on performance and selected biochemical and haematological indicators in female and male broiler chickens was investigated.

Presented results indicate that continuous exposure of broiler chickens to low environmental temperature since $22^{\text {nd }}$ to $42^{\text {nd }}$ day of growth markedly affected feed 
Table 3. Results of the performance and carcass efficiency

\begin{tabular}{|c|c|c|c|c|c|}
\hline \multirow{2}{*}{ Index } & \multirow{2}{*}{ Group } & \multicolumn{2}{|c|}{ Female } & \multicolumn{2}{|c|}{ Male } \\
\hline & & $x \pm \mathrm{SD}$ & $p$ & $x \pm \mathrm{SD}$ & $p$ \\
\hline \multirow{2}{*}{$\begin{array}{l}\text { Live weight } \\
(\mathrm{kg})\end{array}$} & $\mathrm{C}$ & $2.33 \pm 0.26$ & \multirow{2}{*}{0.606} & $2.70 \pm 0.34$ & \multirow{2}{*}{0.313} \\
\hline & $\mathrm{E}$ & $2.27 \pm 0.28$ & & $2.60 \pm 0.37$ & \\
\hline \multirow{2}{*}{$\begin{array}{l}\text { Abdominal fat } \\
(\mathrm{g})\end{array}$} & $\mathrm{C}$ & $27.10 \pm 9.98$ & \multirow{2}{*}{0.136} & $33.28 \pm 8.58$ & \multirow{2}{*}{$0.001 * *$} \\
\hline & $\mathrm{E}$ & $32.18 \pm 10.88$ & & $22.49 \pm 10.94$ & \\
\hline \multirow{2}{*}{$\begin{array}{l}\text { CE of AF } \\
(\%)\end{array}$} & $\mathrm{C}$ & $1.15 \pm 0.43$ & \multirow{2}{*}{0.163} & $1.17 \pm 0.26$ & \multirow{2}{*}{$0.001 * *$} \\
\hline & $\mathrm{E}$ & $1.36 \pm 0.47$ & & $0.8 . \pm 0.40$ & \\
\hline \multirow{2}{*}{$\begin{array}{l}\text { Heart weight } \\
\text { (g) }\end{array}$} & $\mathrm{C}$ & $10.71 \pm 1.70$ & \multirow{2}{*}{$0.000 * *$} & $14.47 \pm 2.16$ & \multirow{2}{*}{$0.000 * *$} \\
\hline & $\mathrm{E}$ & $14.30 \pm 1.92$ & & $17.38 \pm 2.33$ & \\
\hline \multirow{2}{*}{$\begin{array}{l}\text { CE of } \mathrm{HW} \\
(\%)\end{array}$} & $\mathrm{C}$ & $0.46 \pm 0.07$ & \multirow{2}{*}{$0.000 * *$} & $0.51 \pm 0.05$ & \multirow{2}{*}{$0.000 * *$} \\
\hline & $\mathrm{E}$ & $0.60 \pm 0.06$ & & $0.62 \pm 0.07$ & \\
\hline \multirow{2}{*}{$\begin{array}{l}\text { Liver weight } \\
\text { (g) }\end{array}$} & $\mathrm{C}$ & $45.01 \pm 9.72$ & \multirow{2}{*}{0.136} & $58.02 \pm 9.36$ & \multirow{2}{*}{$0.016^{*}$} \\
\hline & $\mathrm{E}$ & $48.82 \pm 5.40$ & & $65.53 \pm 9.50$ & \\
\hline \multirow{2}{*}{$\begin{array}{l}\text { CE of LW } \\
(\%)\end{array}$} & $\mathrm{C}$ & $1.90 \pm 0.36$ & \multirow{2}{*}{0.110} & $2.05 \pm 0.24$ & \multirow{2}{*}{$0.001 * *$} \\
\hline & $E$ & $2.05 \pm 0.19$ & & $2.34 \pm 0.28$ & \\
\hline
\end{tabular}

$\mathrm{CE}$ of AF - carcass efficiency of abdominal fat, CE of HW - carcass efficiency of heart

weight, CE of LW - carcass efficiency of liver weight

$\mathrm{C}$ - control group, $\mathrm{E}$ - experimental group, $x=$ arithmetic mean

$\mathrm{SD}=$ standard deviation, $p=$ test value according to Student's $t$-test

$* p<0.05, * * p<0.01$

conversion, haematocrit and haemoglobin content, weight of some inner organs and certain selected biochemical indicators.

Changes in haematocrit and haemoglobin content induced changes in blood flow resistance that were compensated by modification in cardiac muscle weight. A decline in environmental temperature resulted in significant alterations of a circulatory system. These changes included a significant increase in haematocrit $(p<0.01)$ and haemoglobin content ( $p<0.05$ in female and $p<0.01$ in male broiler chickens). Similarly, the same changes have been observed in fowl exposed to low environmental temperature (Shlosberg et al. 1996; Yahav et al. 1997; Yahav 2002). Yahav (1999) observed a linear relationship ( $\mathrm{r}=0.877$, $p<0.01$ ) between haematocrit and heart weight in turkeys (male BUT) exposed to 15, 25, and $35^{\circ} \mathrm{C}$ from 4 to 8 week of age. This relationship indicated an adaptation of heart mass to the changes in work load associated with the changes in blood flow resistance. We also observed these changes in our experiment. We confirmed that the decline in environmental temperature led to a significant increase in heart $(p<0.01)$ and liver $(p<0.05$ in male broiler chickens) weight. Acclimatization to low environmental temperatures involves changes in abdominal fat content, because in cooler environment more energy is dissipated as heat and thus fat accumulation declines (Suk and Washburn 1995; Yahav et al. 1996). Yunianto et al. (1997) observed that abdominal fat content decreased with decreasing temperature, in broiler chickens kept at $16^{\circ} \mathrm{C}$ it was five times lower than in the birds kept at $34{ }^{\circ} \mathrm{C}$. Our findings are rather different from the statement of Yunianto et al. (1997) as only in the experimental male group low environmental temperature caused a decline in abdominal fat content $(p<0.01)$. In the experimental female group, abdominal fat content was higher than in the control female group, but no significance was found.

Temperature had no effect on body weight. Body weight difference between experimental and control groups of female and male broiler chickens was not significant. Similarly, Yahav (1999) reported that body weight in turkeys exposed to $15^{\circ} \mathrm{C}$ was lower than in turkeys exposed to $25^{\circ} \mathrm{C}$ (from 4 to 8 week of age), but these values were not significantly changed. 
Triiodothyronine $\left(\mathrm{T}_{3}\right)$, a hormone influencing feed intake and weight gain, is one of the factors affected by ambient temperature (Yahav et al. 1996; Yahav 1999). Plasma concentration of triiodothyronine is inversely related to environmental temperature (Stojević et al. 2000). In the present study, significant $(p<0.01)$ changes in plasma triiodothyronine concentration were observed. The values of plasma $\mathrm{T}_{3}$ were found 1.03 and $0.98 \mathrm{ng} \cdot \mathrm{ml}^{-1}$, and 1.84 and $2.59 \mathrm{ng} \cdot \mathrm{ml}^{-1}$ in control (female and male) and experimental (female and male) groups, respectively. Yahav (2002) reported that concentrations of plasma triiodothyronine in turkeys exposed to 10,20 , and $30^{\circ} \mathrm{C}$ from $4^{\text {th }}$ to $8^{\text {th }}$ week of age were $2.68,2.06$, and $1.21 \mathrm{ng} \cdot \mathrm{ml}^{-1}$, respectively.

In the present study, low environmental temperature also influenced other biochemical parameters. According to our experimental results, we detected that low environmental temperature caused a significantly increased level of total proteins $(p<0.05)$, uric acid $(p<0.05)$ and phosphorus $(p<0.05$ in female and $p<0.01$ in male broiler chickens). In addition, in the experimental male group, the low environmental temperature led to significantly increased level of glucose $(p<0.05)$. Yahav et al. (1997) studied the effect of shifts in environmental temperature in Cobb male broiler chickens. They reported that the concentration of plasma total proteins was significantly higher $(p<0.05)$ in groups exposed to low environmental temperature $\left(10^{\circ} \mathrm{C}\right.$ for 4 weeks $)$.

In conclusion, it can be stated that the environmental air temperature is one of the most significant abiotic factors that can significantly influence metabolism and subsequently the production of broiler chickens.

\section{Vliv snížené teploty vnějšího prostředí na užitkovost a na vybrané krevní ukazatele u brojlerových kuřat (Gallus domesticus)}

Cílem práce bylo posoudit vliv snížené teploty prostředí na růst, konverzi krmiva, užitkovost a vybrané biochemické a hematologické ukazatele. Zjištěné výsledky potvrdily, že snížená teplota od 22. dne výkrmu významně $(p<0,05)$ ovlivnila hladinu celkových proteinů, kyseliny močové, fosforu (u slepiček), hemoglobinu (u slepiček), glukózy (u kohoutků) a hmotnost jater (u kohoutků). Teplota dále významně $(p<0,01)$ ovlivnila také hladinu fosforu (u kohoutků), trijódthyroninu, hemoglobinu (u kohoutků), hematokritu, a obsah abdominálního tuku (u kohoutků) a hmotnost srdce. Výsledky tedy zřetelně potvrzují, že v průběhu růstu pokles teploty vnějšího prostředí (chladový stres) negativně ovlivňuje některé ukazatele produkce a vybrané ukazatele krevního systému.

\section{Acknowledgement}

This research was supported by the Ministry of Education, Youth and Sports of the Czech Republic (MSM 6215712402).

\section{References}

AENGWANICH W, SIMARAKS S 2004: Pathology of heart, lung, liver and kidney in broilers under chronic heat stress. Songklanakarin J Sci Technol 26:417-424

CAHANER A, LEENSTRA F 1992: Effects of high temperature on growth and efficiency of male and female broilers from lines selected for high weight gain, favorable feed conversion, and high or low fat content. Poult Sci 71: 1237-1250

DARRAS VM, VAN DER GEYTEN S, KÜHN ER 2000: Thyroid hormone metabolism in poultry. Biotechnol Agron Soc Environ 4: 13-20

DOUBEK J, BOUDA J, DOUBEK M, FÜRLL M, KNOTKOVÁ Z, PEJŘILOVÁ S, PRAVDA D, SCHEER P, SVOBODOVÁ Z, VODIČKA R 2003: Veterinární hematologie. Noviko Brno, 464 p. (in Czech).

KLANDORF H, HARVEY S 1985: Food intake regulation of circulating thyroid hormones in domestic fowl. Gen Comp Endocrinol 60: 162-170

MANNING RO, WYATT R 1990: Effect of cold acclimatisation on the broilers chicks resistance to acute aflatoxicosis. Poult Sci 69: 388-396 
SHINDER D, LUGER D, RUSAL M, RZEPAKOVSKY V, BRESLER V, YAHAV S 2002: Early age cold conditioning in broiler chickens (Gallus domesticus): thermotolerance and growth responses. J Thermal Biol 27: $517-523$

SHLOSBERG A, BELLAICHE M, ZEITLIN G, YA'ACOBI M, CAHANER A 1996: Haematocrit values and mortality from ascites in cold-stressed broilers from parents selected by haematocrit. Poult Sci 75: 1-5

SUK YU, WASHBURN KW 1995: Effects of environment on growth, efficiency of feed utilization, carcass fatness, and their association. Poult Sci 74: 285-296

STOJEVIĆ Z, MILINKOVIĆ-TUR S, ĆURČIJA K 2000: Changes in thyroid hormones concentrations in chicken blood plasma during fattening. Vet Arhiv 70: 31-37

YAHAV S 1999: The effect of constant and diurnal cyclic temperatures on performance and blood system of young turkeys. J Therm Biol 24: 71-78

YAHAV S 2000: Domestic fowl-strategies to confort evironmental conditions. Avian Poult Biol Rev 11: 81-95

YAHAV S 2002: Limitations in energy intake affect the ability of young turkeys to cope with low ambient temperatures. J Therm Biol 27: 103-108

YAHAV S, GOLDFIELD SI, PLAVNIK I, HURWITZ S 1995: Physiological responses of chickens and turkeys to relative humidity during exposure to high ambient temperature. J Therm Biol 20: 245-253

YAHAV S, STRASCHNOW A, PLAVNIK I, HURWITZ S 1996: Effect of diurnal cycling versus constant temperatures on chicken growth and food intake. Br Poult Sci 37: 43-54

YAHAV S, STRASCHNOW A, PLAVNIK I, HURWITZ S 1997: Blood system response of chickens to changes in environmental temperature. Poult Sci 76: 627-633

YUNIANTO BVD, HAYASHI K, KANEDA S, OHTUSKA A, TOMITA Y 1997: Effect of environmental temperature on muscle protein turnover and heat production in tube-fed broiler chickens. Br J Nutr 77: $897-909$ 